\title{
Impact of Work Stress, Ego Depletion And Work Absorption On Leader's Humbleness
}

\author{
Saima Tabassum \\ Asif Hussain Samo \\ \& \\ Saima Wakeel \\ Department of Business Administration \\ Sindh Madressatul Islam University
}

\begin{abstract}
Leader's humbleness plays an indispensable role in influencing and motivating the followers. It is also significant to study the precursors which augment or mitigate that humility. This study was conducted to empirically test the impact of work stress, ego depletion, and work absorption on the leader's humility. With the quantitative approach, numeric data was collected from 327 employees of private companies who are at leading positions. Instruments were adopted from previous studies. The result revealed that if leaders face work stress and ego depletion, their humbleness starts vanishing, whereas when they are more absorbed in their work, they become humbler. This study is beneficial for companies who want their leaders to become humble with their followers and peers.
\end{abstract}

Keywords: Work Stress; Ego Depletion; Work Absorption; Humility.

\section{تلخيص}

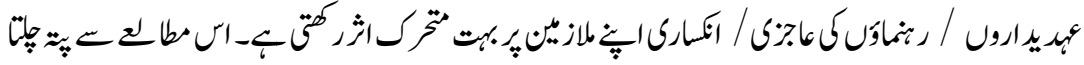

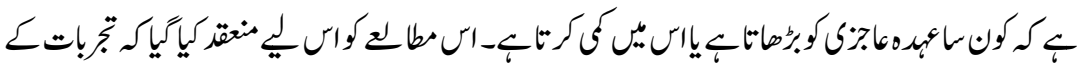

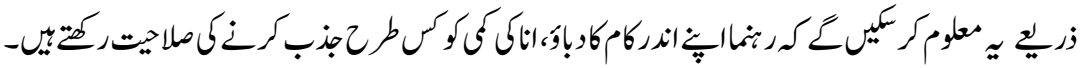



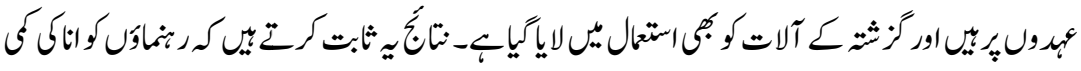

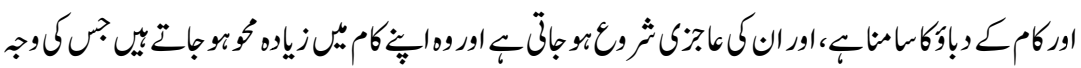

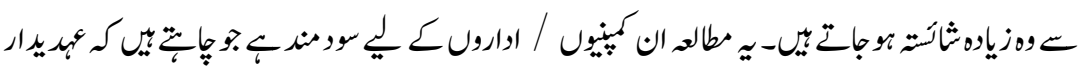

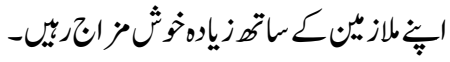

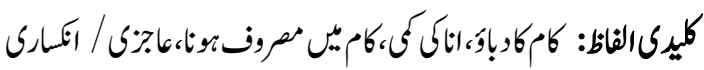




\section{Introduction}

Leadership humility has drawn significant attention from scholars as organizations have started considering it as one of the core values of the company's moral foundation. The leadership humility concept is about providing room for imperfections, mistakes, and a gap of knowledge, which does not cause low self-esteem. In summarized way, humility in a leader is authentic when it covers the three dimensions of self-awareness, openness to transcendence, but it's not necessary that a leader has to be constantly perfect in the above three dimensions to be known as humble(Morris et al., 2005). The contradiction about leadership humility is that no one can claim to have it achieved completely (Tangney, 2002).A researcher concluded that Leadership humility is one of the most virtuous and honorable concepts if it is utilized to a defined limit as a way of self-defense and utilized marvelously that it becomes a sign of strength which consequently gives a feeling of joy and self-mastery in use(Owens et al., 2012).

Work absorption is a positive state of mind associated with the work-related wellness recognized by dedication and motivation towards work. Employees who have increased levels of work absorption are also high in energy and more motivated in performing well. Employees can perform poorly instead of work engagement but, employees having high energy as a consequence of work absorption are more likely to manage or discover the resources for work at the time of need. work absorption is not only beneficial for employee's individual performance, but it also provides an opportunity for organizations to perform in the best manner (Wilmar B. Schaufeli et al., 2006). The organization should not wait for employees to feel demotivated in order to make them feel work engaged or absorbed, but the organizations should keep maintaining a climate to keep employees work absorbed and engaged, which makes an organization an attractive recruiter (Salanova et al., 2005).

Ego depletion is a mental condition that occurs when a person loses personal resources as a result of prior self-control exertion. Ego depletion model shows that a person has limited amount of resources to manage willful tasks named as ego strength, which can be absorbed or depleted during self-control practices but it's also recovered with the passage of time, so ego depletion is also important to explain the reasons of self-control failure (Tice et al., 2007). Ego depleted people are more exhausted and have a decreased level of motivation to perform well (Webb \& Sheeran, 2003). Research shows that self-affirmation does not help to manage self-control when ego depletion is absent, on the other hand, just selfaffirmed people can lessen the damaging effects of ego depletion (Schmeichel \& Vohs, 2009). 
Work stress is an emotional state that appears in the human mind, i.e., "depression" which increases day by day. Depression can disturb professional as well as personal life. At organizational level and as a leader it can cause low job satisfaction, high turnover and insufficient human resources (Lin, Cheng, Wu, \& Ou-Yang, 2016). Different leadership styles show different outcomes, which can have a bad impact on the employee's behavior directly or indirectly. It is important that we should relate leader's behavior with employees in a positive way because the achievements and good performance of employees are totally based on leadership style of a leader (Haq \& Kuchinke, 2016). It is very common among employees that leaders are a major source of stress for their subordinates. During recent years, the phenomena of stress have got intensified between employees and management, few studies have focused on the behavior of leaders and their leadership styles and their impact on employees and employee's performance in an organization (Blase et al., 1986). This study also examines the impact of work stress on leadership humility with other variables. The leadership style plays an important role in empowering employees and motivating the inactive mind for the betterment of the organization, so it becomes important for leaders to focus on goals and adopt proactive behavior(Cheong et al., 2016). Nowadays, the topic of leadership and leadership styles has gained the attention of the researchers focusing the positive side of leadership, but no one is pointing some destructive side of leaders, which is a serious topic. This kind of leadership proves to be fatal for organizations. It is concluded that work stress is a major cause in aggressive behavior of leaders and followers (Hadadian \& Zarei, 2016). Leadership humility allows leaders to find out weaknesses and strengths of them and to utilize the input of others in an appropriate manner. Ego depletion, work stress, and work absorption are negative factors that occur during the management of work. "This study aims to determine the impact of ego depletion, work stress, and work absorption on leadership humility."

\section{Review of Literature}

\section{Theoretical Background Humility}

The word 'Humility' is basically a Latin word, and it came from 'Humus,' which means ground or earth. Being humble means having a disciplined view of him or her or others. A disciplined attitude means enabling a person to grant his or her strengths or weaknesses in the absence of higher-level or lower-level feelings. The literature suggests that the researchers unify humility with empathy, narcissism, low self-esteem, honesty, modesty, and integrity, but these are far distinct from humility. Some people also consider humility as a personality trait, an orientation, a value, or a psychological strength or a virtue (Rego et al., 2017). 
Today the important need of the world is the humility with brilliance. A person who is totally filled with self-importance cannot state to be humble. Humility recognizes that no one is perfect and free of faults; as a result, it accepts others' perceptions and views as well. Humility is an empathetic attitude which a leader should show and stick to it. Handling the critical situations calmly and peacefully is a medium to success. The best leader listens more and turns his voice down and wish to understand what others want to say. A humble leader is with the ability to teach and speaks against error, and between correction and humbleness, there is no conflict (Eragula, 2015).

\section{Leadership}

Leadership is a broad and complex idea. Leadership is a way of guidance for teams, groups, or any individual. Leadership style plays a vital role in building an effective and creative team, and a leaders influence individuals through their skills and experience. The style of leadership also depends on the culture of a specific area. A leader is an influential link between the organizational goals, mission and team works (Merrill, 2015). Leaders not only follow their own thoughts but also focus their follower's perception and thinking. Nowadays, leadership is becoming more important due to the volatile and complex business world. A leader makes constructive changes and builds a creative image of faraway future and implements strategies to fulfill the necessary changes. Leadership is characterized as the fundamental activity of a leader being involved in making changes and setting directions for the future (Răducan \& Răducan, 2014). In an organization, leadership is a responsibility of continuity. Leadership is the ability to motivate their followers towards the effectiveness of organization and success. Unmotivated employees neither pay attention and nor efforts in their jobs, and they start avoiding going to the workplace and display poor quality work (Kappen,2010).Leadership is an art that inspires others to fight in search of hope. From this outlook, leadership is an evoke which motivates followers by making long term vision riveting, challenging for a unique future. When these visions combine with the mission, it makes organizational culture, values, and success (Fry, 2003).

\section{Leadership and humility}

Humble leaders is talented and attracts willing people for their team. Humble leaders not only see one side of the picture, but he sees overall the big picture. He knows that success is an unpredictable chance which can be acquired by the small achievements of individuals. Humble leaders do not be shy in accepting their fault and keep on learning something new; he does not blame others for his mistakes. A mature and humble leader is one who listens and invites his team in an open conversation rather than dodging others for ensuring success and problem- 
solving. Their leadership style of such leaders is humble and selfless (Prabhu, 2016). When a leader declares his mistakes, he shines like a spotlight in front of his followers. But there is a very little real understanding of leadership humility, which influences leaders in a deep-level of character development and strengthens them. The purpose of this study is to induce the importance of leader humility when a team receives humility in the workplace; it creates strength in team and leader as well. In short, the humble behaviour of leaders empowers followers both collectively and individually to experience high capability and confidence in the workplace (Rego et al., 2019).

\section{Hypotheses}

Work stress is an increasing headache of companies, especially those which are upgrading their structures. There are reasons for work stress: Companies are being failed to provide job security to employees, additionally suffocating environment which does not allow creativity and open communication also cause work stress (Naseem, 2018). Work stress is the problem which is less clearly reported by the managers (Cavanaugh, Boswell, Roehling \& Boudreau, 2000). Researchers have conducted a meta-analysis and established that work stress in case of lesser control could be followed by an increased risk of cardiac disease. They conclude that prevention should be done by decreasing the work stress with the help of improving the psychological working conditions ( $\mathrm{Li}$ et al., 2015). Job stress is the element that can force an employee to become demotivated, poor performer as well as depressed or physically ill. It has been revealed that work stress can lead to leaving the job or absences. It is not surprising that there is a negative correlation between work stress and job satisfaction (Lu et al., 2017). Stressors have a link with the physical health of employees, but working conditions determine the level of work stress on the employee. Harder the working conditions greater the work stress. People in servicing businesses have to be more interactive as the result of which the work stress level is also high in service. The impact of complexity on work stress has been examined which exerts that complexity has negative effect on work stress (Pugliesi, 1999).A number of researches have been done on work stress, but the purpose of this research is to find out the impact of work stress on behavior of leaders. Stress occurs when a lot of complex situation happens like burden of office work, tight deadlines and boss behaviors. Work stress is a major cause of bad mental health, aggressive behavior, shouting and some other behaviors like these. A leader is the main stair of success for any organization. A leader's behavior is the most important source of success for any organization. Leadership is a guide and direction for team members towards any goal or objective. Leadership is the exhibition of regulative action, promotion, two-way communication, decision making, reinforcement and interpersonal relationship with their group members and followers. Leaders should be transparent and engaged in their concerned decision, along with 
humbleness. Leaders and followers bond should be pleasurable and highly committed. Humble leaders are the best leaders for their followers as well as organizations (Elçi et al., 2012). The authoritative or dominant role of leaders for followers is a potential settlement with their own work pressure if they will not be able to overcome their stress so they cannot be able to manage their team. There can be two possibilities for work stressors that can be seeking in future work. First, stress can be a force towards negative behavior of leadership due to the workload and can cause narrow-minded perceptions to their followers due to the higher stress conditions. Stressful situations often cause ineffective behavior in performing jobs. Second, we can predict that highly emotional stable people can overcome their emotions on work stress. We, thus, hypothize that;

H1: Work stress negatively impacts leadership humility.

Work environment having resources can boost the level of work absorption of employees, and it can indirectly leave an impact on performance. Work absorption is favorable and work-related state of mind that can be characterized by commitment and enthusiasm(W B Schaufeli, 2011). Another finding suggests a strong relationship of work absorption with job performance; work absorbed employees contemplate all dimensions of work as their own domain, so they are up for playing roles that are not included in their job description to achieve organizational goals(Christian et al., 2011). Employees having more sense of work absorption are able to play their job roles more effectively, they have capability to perform proactively, while number of researches on work absorption is being done and still researchers have not agreed on the same definition of work absorption which is considered a dimension of work engagement along with dedication and vigor. There are many things that are yet to be explored in work absorption phenomenon like relationship of absorption is still unknown with leadership (Bakker, 2011). Experimental research revealed that positive and helpful events cause work absorption to be increased directly (Below, Schmitt, Frese, \& Kühnel, 2011). A case study finds it believable that if employees are more work absorbed, they can enjoy a better relationship with their leader, or employees who perform well can get more work absorbed than others (Authors, 1992). It's found that work absorption and satisfaction of employees are linked with meaningful business outcomes to the extent which is important to the organization, and this relationship can be observed over the company (Harter et al., 2002). Resources cause work absorption to be increased whereas, in case of increasing work absorption, job demands estimated as challenge proved to be helpful, and job demands estimated as barrier can be damaging (Crawford et al., 2010). Prospering interventions can be considered as useful methods of increasing level of work absorption (Knight et al., 2017). Work absorption is 
found to be a steady phenomenon as its level is not affected by the passage of time (Mauno et al., 2007). The research hypothesized and found that there is positive relationship between work absorption and charismatic leadership (Babcock-Roberson \& Oriel, 2102). According to a study, if fresh employees are associated with authentic leaders then they feel more engaged and experience high level of work satisfaction (Giallonardo et al., 2010). An authentic leadership develops trust of employees in leadership which results in work absorption among employees, organizations which put great efforts in relationship of employee and leaders are known as good where employees enjoy working. If a leader creates transparent environment and does not prefer self-interest, he develops trustable relationship with employees which causes employees to feel work absorption (Hassan \& Ahmed, 2011). Lower level leaders by showing humbleness and action leave impact on wok engagement, whereas, combination of action and leadership humility generates works absorption at the higher hierarchical ranks (Sousa \& van Dierendonck, 2017). Reviewing the literature provides that impact of work engagement is examined on many variables. Even impact of leadership humility on work absorptions is also investigated, but this study aims to investigate the impact of work absorption on the humility of leaders.

H2: Work absorption positively impacts leadership humility.

A study found that ego depletion functions by automatic processing channels in leaders; outside of leader's control. In addition, display of ethical behaviour without starting structure and consideration behaviour has a dark side, which increases the possibility that leaders will be eventually abusive because continuously showing ethical behaviour can cause mental fatigue and moral credits in a leader(Lin, Ma, \& Johnson, 2016). The depletion of ego is the result when a person has to make many decisions no matter the one likes or dislikes the task. Depletion comes from continuously thinking and comparing choices out of many options (Baumeister et al., 2008). Display of integrity and honesty is negatively affected by ego depletion in self-control; there is considerable relationship between ego depletion and integrity in prediction of off-task behaviour. During an examination it was found that integrity predicts self-control, not in the presence of ego depletion (Bazzy \& Woehr, 2017). Ego depletion is considered as a consequence of voice behaviour in organizations, but it's unclear yet how voice behaviours are regulated how it impacts practicing ego depletion and self-control. Voice behaviours affect mental fatigue of employees, promote behaviour lined with a decrease in depletion whereas prohibitive behaviour is linked with increased depletion hence voice behaviour appears to be at cost 
because reliability of work behaviours is deteriorated by depletion (Lin \& Johnson, 2015). People seek ways to be engaged by activities which satisfy the needs of competence and autonomy it has been found that activities which a person performs intentionally or willingly are autonomous activities do not appear to be ego depleting (Ryan \& Deci, 2008). The association of ego depletion is observed with aggression. In experimental study, participants in the ego-depletion state displayed increased aggression towards experimenter as compared to the participants in the controlled state; the behaviour was evaluated as participants who were in ego depletion state were frustrated and aggressive due to the restrictions (Gersch, 2012). The work of leaders is challenging, and they have to face difficult situations that can decrease their self-control resources. Leaders who have a high level of self-control are found to be less influenced by the depleting impacts of their surface acting as compared to their peers (Yam et al., 2016). Humility is believed to be motivating in strengthening social connectivity and bonds also help in repairing the relationships. Humility is associated with selfregulation, and on the other hand ego-depletion tasks can be discouraging for a person's trait to act in a humble manner(Davis et al., 2013).Various aspects and influences of ego depletion are examined but influence of ego depletion on leadership humility is yet to be researched, so a part of this study aims to find it out.

H3: Ego depletion negatively impacts on leadership humility.

\section{Conceptual Framework}






\section{Methodology \\ Research Design}

With philosophical underpinnings in positivism thought, this study followed a quantitative research method. Numeric data were collected through adopted instruments from previous studies. The validity of instruments has already been testified in literature. For data collection we used survey method, and instruments were designed in closed-ended structured questionnaires.

\section{Sampling}

We aimed to test the hypothesized model on employees of private companies who are at leading positions and have been assigned, in any way, supervision, managerial or leadership role. Since the sampling frame was not available, we opted for non-probability convenient sampling technique. As far as the sample size is concerned, we distributed 400 questionnaires to the targeted employees, out of which we received 255. Out of 255, 28 were further discarded as they were not filled properly. The sample size for final analysis remained 227.

\section{Analysis}

We tested the relationship between variables with correlation test, and then to further test the hypotheses and the relevant impact, we applied multiple regression analysis through SPSS. The extent of variance was measured by the r square test.

\section{Measurement of Instrument}

Work stress instrument is adapted from an article (Adams et al., 1996). The instrument of leadership humility is adopted by an article (Owens et al., 2013). The work absorption instrument is adapted from an article (Rothbard, 2006). Whereas ego depletion instrument was developed from multiple previous pieces of research.

\section{Results}

Table: 4.1.

Descriptive statistics

\begin{tabular}{|l|c|c|c|}
\hline & Mean & Std. Deviation & N \\
\hline Total LH & 32.4190 & 7.58947 & 327 \\
\hline Total WA & 11.6606 & 3.52089 & 327 \\
\hline Total WS & 32.3670 & 7.53966 & 327 \\
\hline Total ED & 26.8226 & 7.72727 & 327 \\
\hline
\end{tabular}


Table 4.1 shows that data consists of 327 respondents. Leadership humility (LH) is a dependent variable, whereas work absorption (WA) and Ego depletion (ED) and work stress are independent variables.

Table: 4.2

Regression analysis

\begin{tabular}{|l|c|c|c|c|c|}
\hline \multirow{2}{*}{ Model } & \multicolumn{2}{|c|}{$\begin{array}{c}\text { Unstandardized } \\
\text { Coefficients }\end{array}$} & $\begin{array}{c}\text { Standardized } \\
\text { Coefficients }\end{array}$ & & \multirow{2}{*}{} \\
\cline { 2 - 5 } & $\mathrm{B}$ & Std. Error & Beta & $\mathrm{t}$ & Sig. \\
\hline (Constant) & 28.696 & 2.031 & & 14.131 & (Constant) \\
\hline TOTALWA & .820 & .108 & .370 & 7.594 & $* * *$ \\
\hline TotalED & -.201 & .053 & -.219 & -3.765 & $* * *$ \\
\hline TotalWS & -.097 & .042 & -.134 & -2.330 & $* * *$ \\
\hline
\end{tabular}

Table 4.2 shows that all three independent variables have a significant impact on leadership humility. Work absorption has positive impact on leadership humility up to the level that with one unit increase in work absorption, leadership humility goes up by 0.37 . However, with one unit increase in ego depletion, leadership humility goes down by 0.219 , which show negative impact. Moreover, with one unit increase in work stress, leadership humility goes down by 0.134 , which again shows negative impact. These results show that all three hypotheses of the study are accepted.

Table: 4.3

Model summary

\begin{tabular}{|l|r|r|r|r|}
\hline Model & R & R Square & Adjusted R Square & $\begin{array}{c}\text { Std. Error of the } \\
\text { Estimate }\end{array}$ \\
\hline 1 & $.560^{\mathrm{a}}$ & .314 & .307 & 6.31615 \\
\hline
\end{tabular}

In table 4.3 , value of adjusted $\mathrm{R}$ square is 0.560 which means ego depletion, work absorption, and work stress explain 30\% variance in leadership humility.

\section{Discussion \& Recommendations}

The results are consistent with the notion that there is a significant influence of ego depletion, work absorption, work stress, and ego depletion on leader's humbleness. The results suggest that there is positive impact on leadership humbleness by work absorption. The more the leaders will be engaged in their work more, they will be humble. A number of researches are done on impact of 
work absorption; few of them support our hypothesis, such as (Wilmar B. Schaufeli et al., 2006). Some studies have proved to be opposite in results or having reverse phenomenon as compared to our hypothesis that leadership style influences the level of work absorptions and engagement: authentic leadership style of leader (Giallonardo et al., 2010), method (Hassan \& Ahmed, 2011), leader's humility (Sousa \& van Dierendonck, 2017) induce the work absorption in employees at workplace. Whereas the availability of all necessary resources at workplace stimulates the sense of work engagement in employees (Salanova et al., 2005), which in turn makes them able to perform well (Halbesleben \& Wheeler, 2008). The study also hypothesized the negative impact of ego depletion on leadership humility, which is accepted in the results: the more the leaders will deplete ego in work situations more, his humbleness will be decreased. Which was the extension of previous studies on ego depletion's consequences According to prior studies, impact of ego depletion is found negative as it utilizes the self-control of person and make him mentally exhausted (Hagger et al., 2010), level of self-control is predicted by integrity but not in the presence of ego depletion (Bazzy \& Woehr, 2017), ego depletion doesn't operate while job tasks are done willingly (Ryan \& Deci, 2008). The negative impact of work stress was also examined on the humbleness of leaders during the study, as work stress generally influences negatively at workplace in the presence of work stress; their humbleness will be is affected. Usually work stress is considered as a negative stimulation, people who are more stressed are probable to perceive others less humble which brings negative results of destroying relations (Nonterah et al., 2016).

The employee feels difficult to work in the pressurized environment and makes mistakes, probably as it is revealed in the findings of previous studies (Cavanaugh et al., 2000). Our study has hypothesized that work stress negatively impacts leader's humbleness, which means more the leader is stressed lesser he will be humble. So the overall impact of work stress should be negative, and on the other hand the study reveals surprising results that if there is more work stress more humble the leaders will be. These results were unexpected and needed to be investigated ahead.

\section{Conclusions \& Implications}

In this study, we have found the relationship between work stress, ego depletion, and work absorption with leadership humility to compare the effects of these variables. Every organization wishes to empower their leaders in their work 
settings. Our results thus indicate that individual differences explain which leaders are more predisposed to involve their employees. This theorizing can inform organizational selection practices that seek to actively promote leaders motivation. It illustrates the importance of humility from management perspective; it will enhance knowledge and efficiency of management teams for the organizational performance. The study is helpful in resolving the problems regarding the management of humbleness by leaders in the presence of factors such as ego depletion, work stress, and work absorption. Leaders of corporate sector, industries, and educational institutions will get help on how to manage humbleness in disturbing situations. Followers will get indirect benefit in a way if the study concludes that ego depletion, work stress, and work absorption leave negative impact on leader display of humbleness then leaders will be able to cope with the negative factors by knowing the degree of impact and followers will have suitable environment at workplace.

\section{Future Recommendations}

Examination of the relationship among work stress, work absorption, and ego depletion on leadership humility provides us more valuable insight to motivate leaders. We will recommend researchers to further cover this topic by changing these independent variables means impact of other variable should also be examined on leadership humility or solutions to leaders to be controlled their emotions in a proper way to perform in the right direction for a leader to be effective for his or her organization and in his personal life it also helps to sort out the solutions in different scenarios or to keep the surprising results of the study in mind, further research can be done on relationship of work stress and leadership humility which is revealed as positive relationship in the results unexpectedly.

\section{References}

Adams, G., King L, A., \& King K, W. (1996). Relationships of Job and Family Involvement, Family Social Support, and Work-Family Conflict With Job and Life Satisfaction. Journal of Applied Psychology, 81(4), 411-420. https://doi.org/10.1037//0021-9010.81.4.411

Asrar-ul-Haq, M., \& Kuchinke, K. P. (2016). Impact of Leadership Styles on Employees' Attitude Towards their Leader and Performance: Empirical Evidence from Pakistani Banks. Future Business Journal, vol.2:1, pp.5464. https://doi.org/10.1016/j.fbj.2016.05.002 
Authors, F. (1992). Journal of Managerial Psychology. In Journal of Managerial Psychology (Vol. 7, Issue 4). https://doi.org/10.1108/eb004440

Babcock-roberson, M. E., \& Oriel, J. (2102). The Journal of Psychology: Interdisciplinary and Applied The Relationship Between Charismatic Leadership , Work Engagement, and Organizational Citizenship Behaviors. Work, vol.3:141, pp.37-41. https://doi.org/10.1080/ 00223981003648336

Baumeister, R. F., Sparks, E. A., Stillman, T. F., \& Vohs, K. D. (2008). Free will in consumer behavior: Self-control, ego depletion, and choice. Journal of Consumer Psychology, 18(1), 4-13. https://doi.org/10.1016/j.jcps.2007.10.002

Bazzy, J. D., \& Woehr, D. J. (2017). Integrity, ego depletion, and the interactive impact on counterproductive behavior. Personality and Individual Differences, 105, 124-128. https://doi.org/10.1016/j.paid.2016.09.037

Blase, J., Dedrick, C., \& Strathe, M. (1986). Leadership Behavior of School Principals in Relation to Teacher Stress, Satisfaction, and Performance. The Journal of Humanistic Education and Development, 24(4), 159-171. https://doi.org/10.1002/j.2164-4683.1986.tb00290.x

Cavanaugh, M. A., Boswell, W. R., Roehling, M. V., \& Boudreau, J. W. (2000). An empirical examination of self-reported work stress among U.S. managers. Journal of Applied Psychology, 85(1), 65-74. https://doi.org/10.1037/0021-9010.85.1.65

Cheong, M., Spain, S. M., Yammarino, F. J., \& Yun, S. (2016). Two faces of empowering leadership: Enabling and burdening. Leadership Quarterly, 27(4), 602-616. https://doi.org/10.1016/j.leaqua.2016.01.006

Christian, M. S., Garza, A. S., \& Slaughter, J. E. (2011). Work engagement: A quantitative review and test of its relations with task and contextual performance. Personnel Psychology, 64(1), 89-136. https://doi.org/10.1111/j.1744-6570.2010.01203.x

Crawford, E. R., LePine, J. A., \& Rich, B. L. (2010). Linking job demands and resources to employee engagement and burnout: A theoretical extension and meta-analytic test. Journal of Applied Psychology, 95(5), 834-848. https://doi.org/10.1037/a0019364 
Davis, D. E., Worthington, E. L., Hook, J. N., Emmons, R. A., Hill, P. C., Bollinger, R. A., \& van Tongeren, D. R. (2013). Humility and the Development and Repair of Social Bonds: Two Longitudinal Studies. Self and Identity, 12(1), 58-77. https://doi.org/10.1080/15298868.2011.636509

Elçi, M., Şener, İ., Aksoy, S., \& Alpkan, L. (2012). The Impact of Ethical Leadership and Leadership Effectiveness on Employees' Turnover Intention: The Mediating Role of Work Related Stress. Procedia - Social and Behavioral Sciences. https://doi.org/10.1016/j.sbspro.2012.09.1003

Eragula, R. (2015). Confidence in Leadership. Advances in Economics and Business Management. https://doi.org/2394-1553

Fry, L. W. (2003). Toward a theory of spiritual leadership. Leadership Quarterly, 14(6), 693-727. https://doi.org/10.1016/j.leaqua.2003.09.001

Gersch, M. (2012). Monitoring Integrierte Versorgung - Besondere Versorgungsformen: (kein) Wachstum in Sicht? European Journal of Social Psychology, 36(July 2004), 1-13. http://www.wiwiss.fuberlin.de/fachbereich/bwl/angeschlosseneinstitute/gersch/forschung/monitoring_iv.html

Giallonardo, L. M., Wong, C. A., \& Iwasiw, C. L. (2010). Authentic leadership of preceptors: Predictor of new graduate nurses' work engagement and job satisfaction. Journal of Nursing Management, 18(8), 993-1003. https://doi.org/10.1111/j.1365-2834.2010.01126.x

Hadadian, Z., \& Zarei, J. (2016). Relationship between Toxic Leadership and Job Stress of Knowledge Workers. Studies in Business and Economics, 11(3), 84-89. https://doi.org/10.1515/sbe-2016-0037

Hagger, M. S., Wood, C., Stiff, C., \& Chatzisarantis, N. L. D. (2010). Ego Depletion and the Strength Model of Self-Control: A Meta-Analysis. 136(4), 495-525. https://doi.org/10.1037/a0019486

Halbesleben, J. R. B., \& Wheeler, A. R. (2008). The relative roles of engagement and embeddedness in predicting job performance and intention to leave. Work and Stress, 22(3), 242-256. https://doi.org/10.1080/02678370802383962

Harter, J. K., Schmidt, F. L., \& Hayes, T. L. (2002). Business-unit-level relationship between employee satisfaction, employee engagement, and business outcomes: A meta-analysis. Journal of Applied Psychology, 
vol.87:2, pp.268-279. https://doi.org/10.1037/0021-9010.87.2.268

Hassan, A., \& Ahmed, F. (2011). Authentic leadership, trust and work engagement. *International Journal of Human and Social Sciences, 80(July), 750-756. https://doi.org/10.5281/ZENODO.1075160

Knight, C., Patterson, M., \& Dawson, J. (2017). Building work engagement: A systematic review and meta-analysis investigating the effectiveness of work engagement interventions. Journal of Organizational Behavior, 38(6), 792-812. https://doi.org/10.1002/job.2167

Li, J., Zhang, M., Loerbroks, A., Angerer, P., \& Siegrist, J. (2015). Work stress and the risk of recurrent coronary heart disease events: A systematic review and meta-analysis. International Journal of Occupational Medicine and Environmental Health, 28(1), 8-19. https://doi.org/10.2478/s13382014-0303-7

Lin, S. H., \& Johnson, R. E. (2015). A suggestion to improve a day keeps your depletion away: Examining promotive and prohibitive voice behaviors within a regulatory focus and ego depletion framework. Journal of Applied Psychology, 100(5), 1381-1397. https://doi.org/10.1037/ap10000018

Lin, S. H., Ma, J., \& Johnson, R. E. (2016). When ethical leader behavior breaks bad: How ethical leader behavior can turn abusive via ego depletion and moral licensing. Journal of Applied Psychology, 101(6), 815-830. https://doi.org/10.1037/ap10000098

Lin, T. C., Lin, H. S., Cheng, S. F., Wu, L. M., \& Ou-Yang, M. C. (2016). Work stress, occupational burnout and depression levels: A clinical study of paediatric intensive care unit nurses in Taiwan. Journal of Clinical Nursing, vol.25:7-8, pp.1120-1130. https://doi.org/10.1111/jocn.13119

Lu, Y., Hu, X. M., Huang, X. L., Zhuang, X. D., Guo, P., Feng, L. F., Hu, W., Chen, L., Zou, H., \& Hao, Y. T. (2017). The relationship between job satisfaction, work stress, work-family conflict, and turnover intention among physicians in Guangdong, China: A cross-sectional study. BMJ Open, vol.7:5, pp.e014894. https://doi.org/10.1136/bmjopen-2016-014894

Mauno, S., Kinnunen, U., \& Ruokolainen, M. (2007). Job demands and resources as antecedents of work engagement: A longitudinal study. Journal of Vocational Behavior, vol.70:1, pp.149-171. https://doi.org/10.1016/j.jvb.2006.09.002 
Merrill, K. C. (2015). Leadership Style and Patient Safety: Implications for Nurse Managers. Journal of Nursing Administration, vol.45:6, pp.319-324. https://doi.org/10.1097/NNA.0000000000000207

Morris, J. A., Brotheridge, C. M., \& Urbanski, J. C. (2005). Bringing humility to leadership: Antecedents and consequences of leader humility. In Human Relations. https://doi.org/10.1177/0018726705059929

Naseem, K. (2018). Job stress, happiness and life satisfaction: The moderating role of emotional intelligence empirical study in telecommunication sector Pakistan. Journal of Social Sciences and Humanity Studies, 4(1), 7-14.

Nonterah, C. W., Garthe, R. C., Reid, C. A., Worthington, E. L., Davis, D. E., Hook, J. N., Van Tongeren, D. R., \& Griffin, B. J. (2016). The impact of stress on fluctuations in relational humility as couples transition to parenthood. Personality and Individual Differences, 101, 276-281. https://doi.org/10.1016/j.paid.2016.06.016

Owens, B. P., Johnson, M. D., \& Mitchell, T. R. (2013). Expressed Humility in Organizations: Implications for Performance, Teams, and Leadership. Organization Science, 24(5), 1517-1538. https://doi.org/10.1287/orsc.1120.0795

Owens, B. P., Rowatt, W. C., \& Wilkins, A. L. (2012). Exploring the Relevance and Implications of Humility in Organizations. In The Oxford Handbook of Positive Organizational Scholarship (Issue October). https://doi.org/10.1093/oxfordhb/9780199734610.013.0020

Prabhu, G. M. (2016). Two Leadership Traits: Humility and Ethics. EPHInternational Journal of Science And Engineering, 2(11), 1-10.

Pugliesi, K. (1999). The Consequences of Emotional Labor: Effects. Motivation and Emotion, 23(2), 125-154. https://doi.org/10.1023/A:1021329112679

Răducan, R., \& Răducan, R. (2014). Communication Styles of Leadership Tools. Procedia - Social and Behavioral Sciences, 149, 813-818. https://doi.org/10.1016/j.sbspro.2014.08.326

Rego, A., Owens, B., Leal, S., Melo, A. I., Cunha, M. P. e., Gonçalves, L., \& Ribeiro, P. (2017). How leader humility helps teams to be humbler, psychologically stronger, and more effective: A moderated mediation model. Leadership Quarterly, 28(5), 639-658. https://doi.org/10.1016/j.leaqua.2017.02.002 
Rego, A., Owens, B., Yam, K. C., Bluhm, D., Cunha, M. P. e., Silard, A., Gonçalves, L., Martins, M., Simpson, A. V., \& Liu, W. (2019). Leader Humility and Team Performance: Exploring the Mediating Mechanisms of Team PsyCap and Task Allocation Effectiveness. Journal of Management, 45(3), 1009-1033. https://doi.org/10.1177/0149206316688941

Rothbard, N. P. (2006). Enriching or Depleting? The Dynamics of Engagement in Work and Family Roles. Administrative Science Quarterly, 46(4), 655. https://doi.org/10.2307/3094827

Ryan, R. M., \& Deci, E. L. (2008). From Ego Depletion to Vitality: Theory and Findings Concerning the Facilitation of Energy Available to the Self. Social and Personality Psychology Compass, 2(2), 702-717. https://doi.org/10.1111/j.1751-9004.2008.00098.x

Salanova, M., Agut, S., \& Peiró, J. M. (2005). Linking organizational resources and work engagement to employee performance and customer loyalty: The mediation of service climate. Journal of Applied Psychology, 90(6), 12171227. https://doi.org/10.1037/0021-9010.90.6.1217

Schaufeli, W B. (2011). Work engagement: A key concept of a positive occupational health psychology. Presentation from: 2011 Wellness in the Workplace Conference, Bloemfontein, 1-51.

Schaufeli, Wilmar B., Bakker, A. B., \& Salanova, M. (2006). The Measurement of Short Questionnaire: A Cross-National Study. Educational and Psychological Measurement, 66(4), 701-716. https://doi.org/10.1177/0013164405282471

Schmeichel, B. J., \& Vohs, K. D. (2009). Self-Affirmation and Self-Control: Affirming Core Values Counteracts Ego Depletion. Journal of Personality and Social Psychology, 96(4), 770-782. https://doi.org/10.1037/a0014635

Sousa, M., \& van Dierendonck, D. (2017). Servant Leadership and the Effect of the Interaction Between Humility, Action, and Hierarchical Power on Follower Engagement. Journal of Business Ethics, 141(1), 13-25. https://doi.org/10.1007/s10551-015-2725-y

Tangney, J. P. (2002). Humility. In Handbook of positive psychology (pp. 411419). Oxford: University Press,.

Tice, D. M., Baumeister, R. F., Shmueli, D., \& Muraven, M. (2007). Restoring the self: Positive affect helps improve self-regulation following ego depletion. 
Journal of Experimental Social Psychology, 43(3), 379-384. https://doi.org/10.1016/j.jesp.2006.05.007

Webb, T. L., \& Sheeran, P. (2003). Can implementation intentions help to overcome ego-depletion? Journal of Experimental Social Psychology, 39(3), 279-286. https://doi.org/10.1016/S0022-1031(02)00527-9

Yam, K. C., Fehr, R., Keng-Highberger, F. T., Klotz, A. C., \& Reynolds, S. J. (2016). Out of control: A self-control perspective on the link between surface acting and abusive supervision. Journal of Applied Psychology, 101(2), 292-301. https://doi.org/10.1037/ap10000043

Dr. Saima Tabassum is Chairperson and Associate Professor in the Department of Business Administration, Sindh Madressatul Islam University, Karachi, Pakistan.

Asif Hussain Samo is Lecturer in the Department of Business Administration, Sindh Madressatul Islam University, Karachi, Pakistan.

Saima Wakeel is Student in the Department of Business Administration, Sindh Madressatul Islam University, Karachi, Pakistan. 